GLOBAL JOURNAL OF AGRICULTURAL SCIENCES VOL 9, NO. 1, 2010: 51-55

COPYRIGHT@ BACHUDO SCIENCE CO. LTD PRINTED IN NIGERIA. ISSN 1596-2903

www.globaljournalseries.com; Email: info@globaljournalseries.com

\title{
EFFECTS OF NITROGEN ENRICHMENT ON HEAVY METALS CONTENT OF CATTLE DUNG/POULTRY MANURE COMPOST AND MAIZE YIELD.
}

\author{
N. M. JOHN, U. E. ETOKEREN, I. I. UDO, I. D. EDEM, O. B. IREN AND S. S. ASUQUO
}

(Received 22, January 2010; Revision Accepted 6, July 2010)

\section{ABSTRACT}

The research was carried out at John Ker Nigeria Organo-Mineral Company site at Ikot Ekpene, Akwa Ibom State, Nigeria, to investigate the effect of nitrogen enrichment on contents of heavy metals in cattle dung/poultry manure compost and the growth of maize. Cattle dung was mixed with poultry manure in the ratio of 3:1 volume/volume basis, respectively. The compost treatments were; (i) cattle dung/poultry manure (CDPM), (ii) cattle dung/poultry manure supplemented with $25 \mathrm{~kg}$ of urea $\left(\mathrm{CDPM}_{\cup}\right)$ and (iii) cattle dung $(C D)$ as control composted alone. The compost treatments; CDPM, CDPM and CD were sampled periodically after 2, 6 and 10 weeks of composting for laboratory analysis. After 10 weeks, each of the compost treatments was mixed with $7 \mathrm{~kg}$ of dry soil sample at the rate of 10,20 and $40 \mathrm{t} /$ ha to test its effects on the growth of maize plant for 6 weeks. The enrichment of the CDPM compost resulted in an increase in the levels of all the heavy metals contained in the compost (CDPMu) at two weeks after composting. At 10 weeks of composting, the concentrations of $\mathrm{Fe}, \mathrm{Zn}, \mathrm{Cu}, \mathrm{V}, \mathrm{Mn}$ and $\mathrm{Ni}$ in $\mathrm{CDPM}_{\mathrm{U}}$ compost increased by $32.8,25.6,14.6,40.0,6.8$ and $19.0 \%$, respectively compared with their contents in the CDPM. The C/N ratios ranged from 23.9 to 25.1 in the CD compost, 23.1 to 23.4 in the CDPM compost and 13.6 to 16.9 in the CDPMU compost within the 10 weeks of composting. The influence of the compost treatments on the growth of maize plant indicated that the plant fertilized with $C D P M_{U}$ compost at $40 \mathrm{t} /$ ha were significantly $(P<0.05)$ higher than those fertilized with the same compost treatment at 0,10 and $20 \mathrm{t} / \mathrm{ha}$. Those fertilized with CD and CDPM at the rate of 0 , 10,20 and $40 \mathrm{t} / \mathrm{ha}$, had the same trends respectively.

Key words: Nitrogen Enrichment, Heavy Metals, Cattle Dung, Poultry Manure, Compost.

\subsection{INTRODUCTION}

Application of fertilizers to crops in the humid tropics such as Nigeria is affected by high rate of nutrient losses even when the fertilizers are properly incorporated into the soil. This is caused by the fragile nature of tropical soil, which according to Brady and Weil (1999) is characterized by low activity clay, low water and nutrient holding capacity, low organic matter content and seasonal torrential rains which cause leaching of nutrients and soil erosion.

Manures were the only means of adding extra nutrients to the soil or replacing those removed by crops before mineral fertilizers were introduced (Cook, 1981). Apart from the normal crop rotation and bush fallowing, research on the use of organic manures for arable crop production in Nigeria dates back to more than 60 years starting with the work of Hartley and Greenwood (1933). Proper composting of wastes especially aerobic type in windrows has proved very effective in reducing such problems and enhancing crop yield (Sridhar et al., 1985).

N. M. John, Department of Soil Science, University of N. M. JOHN. U. E. ETOKEREN. I. I. UDO. I. D. EDEN. O. B. IREN AN

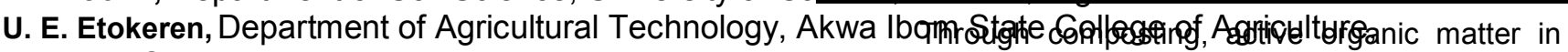
Obiokpa, Nigeria. fresh organic wastes were converted into a source of

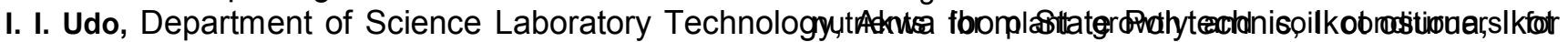
Ekpene, Akwa Ibom State, Nigeria improving the soil physical properties (Hoitink and Fahy, I. D. Edem, Department of Soil Science, University of Uyd,986jo, Qhegeriet. al., 1989). Therefore this research

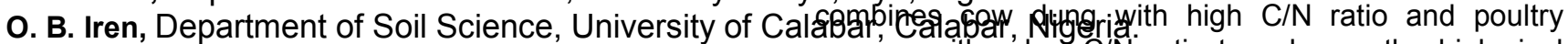

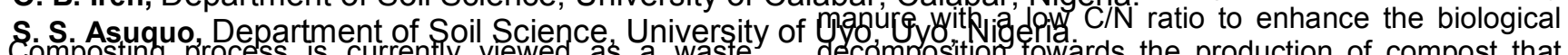
Composting process is currently viewed as a waste decomposition towards the production of compost that management practice used in stabilizing organic wastes, such as manure, yard trimmings, municipal bio-solids and organic urban wastes. Compost is a cured final product of microbial degradation of raw organic wastes used as a soil amendment for crop production (Tyler, 1992). According to John et al., (1995), through composting, organic materials with offensive odour, high moisture, bulkiness and fly infestation are effectively reduced to sweet smelling compost.

Materials with high $\mathrm{C} / \mathrm{N}$ ratio could be mixed with those of lower $\mathrm{C} / \mathrm{N}$ quotient to bring the average ratio of the composite input to a desirable level (Karki and Gairtam, 1994). Animal waste, particularly cattle dung has an average $\mathrm{C} / \mathrm{N}$ ratio of about 24 (Karki and Dixit, 1989). For proper and faster rate of decomposition, materials with high $\mathrm{C} / \mathrm{N}$ ratio should be composted with high nitrogen containing materials, hence increasing the nitrogen content of the materials for increased decomposition. will encourage soil life and plant growth.
2.0 MATERIALS AND METHODS

(a) Physiography of the experimental area: 
The study was conducted at John Ker Nigeria Organo-Mineral Company site, 112b Old Itu Road, Ikot Ekpene Local Government Area, Akwa Ibom State, Nigeria, from April to July 2007. The area is located between Latitude $4^{\circ}$ and $6{ }^{0} \mathrm{~N}$ and Longitude 32 and 34 ${ }^{0} \mathrm{E}$, in the rainforest zone. The air temperature ranges from 26 to $30{ }^{\circ} \mathrm{C}$ and the relative humidity from 75 to $95 \%$. The mean annual rainfall ranges from 2000 to 3000 mm (SLUS-AK, 1989).

\section{(b) Composting process and laboratory analysis:}

Cattle dung (CD) used for the experiment was obtained from Obo-annang market poultry manure collected from a deep litter system at Ritman Farms Limited, both in Ikot Ekpene district. The Cattle dung and poultry manure were mixed thoroughly at the ratio of $3: 1$, respectively and shared into two heaps with one heap incorporated with $25 \mathrm{~kg}$ of urea. The control was cow dung only. The heaps were sufficiently mixed and watered at intervals of four days for the first two weeks, one week for the next one month and monthly, till end of composting after 10 weeks. Ambient and compost temperatures were taken using a thermometer before and after turning. Moisture content of composite samples of the compost was determined by oven drying. Compost and soil samples were collected, air-dried, ground with mortar and pestle, sieved through a $2 \mathrm{~mm}$ sieve before subjecting them to laboratory analysis as follows:

Total nitrogen was determined by micro Kjeldahl digestion method (Jackson, 1962) and organic carbon by Walkley-Black wet oxidation method (Walkley and Black, 1934). Available $P$ was determined using Bray P1 method as described by Bray and Kurtz, (1945). Zn, $\mathrm{Fe}, \mathrm{Mn}, \mathrm{Ni}, \mathrm{V}, \mathrm{Pb}$ and $\mathrm{Cu}$ were read using an atomic absorption spectrophotometer (Michael and Gilliam, 1998).

Data collected from the test crop (maize) were subjected to statistical analysis. Means and Coefficient of Variation ( $\mathrm{CV} \%$ ) were used in evaluating the variability of the nutrient values of the composts their effects on the plants (Gomez and Gomez, 1984).

\section{(c) Pot experiment.}

Seven $\mathrm{kg}$ of soil sample was mixed with 10, 20 and 40 t/ha of each of the compost treatments and put into polythene bags. The control was soil only. Each treatment was replicated four times. The test crop;

maize (Zea mays) was planted at the rate of four seeds per bag and later thinned to two plants. Plant height was taken on weekly basis for six weeks using a measuring tape.

\subsection{RESULTS AND DISCUSSION:}

(a) Composition of fresh organic materials and experimental soil.

The heavy metals content of fresh organic materials (cattle dung and poultry manure) used for composting is presented in Table 1 . The heavy metals content of these materials were low except for high content of iron in both organics and manganese in poultry manure. The lowest content of heavy metals in these materials was found in $\mathrm{Cu}$ and $\mathrm{Ni}$, followed by $\mathrm{V}$ which had a similar content. The content of $\mathrm{Fe}, \mathrm{Zn}, \mathrm{Ni}$ and $\mathrm{Cu}$ were higher in cattle dung than in poultry manure, whereas $\mathrm{Mn}$ and $\mathrm{Pb}$ values were higher in poultry manure than in cow dung. The $\mathrm{C} / \mathrm{N}$ ratio of cow dung (23.7) was greater than that of poultry manure (22.2).

The physico-chemical composition of the soil used for planting and fertilizing the test crop indicated that the soil was sandy loam and moderately acidic in nature (Table 2). The soil organic matter, nitrogen, available phosphorus, exchangeable bases and base saturation contents were low. These are indices of the low fertile status of the experimental soil.

\section{(b) Content of heavy metals in the various composts during composting}

The enrichment of the CDPM compost resulted in an increase in the levels of all the heavy metals contained in the compost $\left(\mathrm{CDPM}_{U}\right)$ at two weeks after composting. There was a high rate of mineralization in the compost supplemented with urea throughout the composting period though their concentrations reduced with time of composting. However, at 6 weeks after composting, $\mathrm{Fe}, \mathrm{Mn}, \mathrm{Zn}$ and $\mathrm{V}$ contents in the enriched compost was still higher than the non-enriched. Only the concentrations of $\mathrm{Fe}, \mathrm{Zn}, \mathrm{Cu}$ and $\mathrm{V}$ in the enriched compost remained constantly higher than that of the non-enriched compost at the $10^{\text {th }}$ week of composting (Table 3).

At the $10^{\text {th }}$ week of composting, $\mathrm{Fe}$ concentration in $\mathrm{CDPM}_{U}$ was $32.8 \%$ higher than its content in the CDPM compost (Table 2). The same was observed for $\mathrm{Zn}$ with $25.6 \%$, Cu with $14.6 \%$, V with $40.0 \%, \mathrm{Mn}$ with $6.8 \%$ and $\mathrm{Ni}$ with $19.0 \%$. The concentration of $\mathrm{Mn}$ in $\mathrm{CDPM}_{\mathrm{U}}$ compost reduced by $42.5 \%$ compared with that of CDPM compost. Similar trend was observed for $\mathrm{Pb}$ with $54.9 \%$, Ni with $35.5 \%$ and $\mathrm{V}$ with $66.6 \%$ increases in concentration.

Micronutrients (Fe, $\mathrm{Cu}, \mathrm{Zn}$ and $\mathrm{Mn}$ ) concentrations in these composts were higher than the concentrations of the other heavy metals, viz; $\mathrm{Pb}, \mathrm{Ni}$ and $\mathrm{V}$ throughout the composting period.

The $\mathrm{C} / \mathrm{N}$ ratios of both the enriched and nonenriched composts were within the limit for the mineralization of the essential elements in these 53 EFFECTS OF NIT

composts. These ratios ranged from 23.1 to 23.4 in the CDPM compost and 13.6 to 16.9 in the $\mathrm{CDPM}_{U}$ compost within the 10 weeks of composting (Table 3). The lower $\mathrm{C} / \mathrm{N}$ ratio of the enriched compost than the non-enriched compost treatments might have resulted from the supplementation of the compost with a mineral nitrogen source that had increased the supply of nitrogen for microorganisms involved in the decomposition of the organic materials in the urea enriched compost. Comparing the levels of these nutrients to the work of Canet (2000), they are within the same range of concentration. Generally, the concentrations of all the elements are within international standard as required by plant for good productivity.

\section{(c) Influence of applied compost on fresh and dry weights of maize plant}

The fresh and dry weights of maize plant at different rates of application of cattle dung/poultry manure compost at 6 weeks after planting (WAP) are 
presented on Figure 1. The result indicated that there was no significant $(P>0.05)$ difference in both fresh and dry weights of plant fertilized with CDPM and $C D P M_{U}$ both at $40 \mathrm{t} \mathrm{ha}^{-1}$ but were significantly $(P<0.05)$ taller than those fertilized with $C D$ at 10,20 and $40 \mathrm{t} \mathrm{ha}^{-1}$,
CDPM and $\operatorname{CDPM}_{\cup}$ both at 10 and $20 \mathrm{t} \mathrm{ha}^{-1}$ and soil only.

This implies that the enriched cattle dung/poultry manure compost and its high rate of application increased the fresh and dry matter weights of maize plant.

TABLE 1: Heavy metals content of fresh organic materials used for the composting

\begin{tabular}{lrrrrrrr}
\hline $\begin{array}{l}\text { Fresh organic } \\
\text { material }\end{array}$ & $\mathrm{Fe}$ & $\mathrm{Mn}$ & $\mathrm{Zn}$ & $\mathrm{Cu}$ & $\mathrm{Ni}$ & $\mathrm{Pb}$ & $\mathrm{V}$ \\
& & & & & & & \\
\cline { 2 - 9 } & 996.80 & 746.40 & 181.80 & 14.68 & 14.38 & 189.60 & 16.48 \\
\hline $\begin{array}{l}\text { Poultry manure } \\
\text { Cattle dung }\end{array}$ & 1120.40 & 114.60 & 366.40 & 18.32 & 18.96 & 148.20 & 16.42 \\
\hline Mean & 1058.60 & 430.50 & 274.10 & 16.50 & 16.67 & 168.90 & 16.45 \\
\hline
\end{tabular}

Table 2: The physio-chemical properties of the experimental soil before planting.

\begin{tabular}{|c|c|c|c|c|c|c|c|c|c|c|c|c|c|c|}
\hline Properties & $\begin{array}{l}\text { Sand } \\
(\%)\end{array}$ & $\begin{array}{l}\text { Silt } \\
(\%)\end{array}$ & $\begin{array}{l}\text { Clay } \\
\text { (\%) }\end{array}$ & $\mathrm{pH}$ & $\begin{array}{l}\text { Org. } \\
\text { mat. } \\
(\%)\end{array}$ & $\begin{array}{c}\mathrm{N} \\
(\%)\end{array}$ & $\begin{array}{l}\text { Avail. } \\
\mathrm{P} \\
\mathrm{mg} \\
\mathrm{kg}^{-1}\end{array}$ & $\begin{array}{l}\text { Exch } \\
\mathrm{K} \\
\end{array}$ & $\begin{array}{l}\text { langeable } \\
\mathrm{Ca} \\
\mathrm{cmol} \mathrm{kg}^{-1}\end{array}$ & $\begin{array}{l}\text { catio } \\
\mathrm{Mg}\end{array}$ & $\stackrel{\mathrm{n}}{\mathrm{Na}}$ & $\begin{array}{l}\text { E.A } \\
\text { (cmol } \\
\left.\mathrm{kg}^{-1}\right)\end{array}$ & $\begin{array}{l}\text { ECE } \\
\mathrm{C} \\
\left(\mathrm{cmol}^{-1}\right. \\
\left.\mathrm{kg}^{-1}\right)\end{array}$ & $\begin{array}{l}\text { Base } \\
\text { sat. } \\
(\%)\end{array}$ \\
\hline Content & 80.4 & 9.4 & 10.2 & 5.2 & 2.16 & 0.09 & 107.8 & 0.08 & 2.26 & 1.10 & 0.06 & 3.58 & 7.08 & 49.44 \\
\hline
\end{tabular}

TABLE 3: Some heavy metals content of the cow dung/poultry manure compost with time of composting.

\begin{tabular}{|c|c|c|c|c|c|c|c|c|c|}
\hline \multirow{2}{*}{$\begin{array}{l}\begin{array}{l}\text { Time of } \\
\text { composting } \\
\text { (weeks) }\end{array} \\
\end{array}$} & \multirow{2}{*}{$\begin{array}{l}\text { Compost } \\
\text { treatment }\end{array}$} & \multicolumn{6}{|c|}{ Heavy metals $\left(\mathrm{mgkg}^{-1}\right)$} & \multirow{2}{*}{\multicolumn{2}{|c|}{$\mathrm{C} / \mathrm{N}$}} \\
\hline & & $\mathrm{Fe}$ & $\mathrm{Mn}$ & $\mathrm{Zn}$ & $\mathrm{Cu} \quad \mathrm{F}$ & $\mathrm{b} \quad \mathrm{Ni}$ & $\mathrm{V}$ & & \\
\hline \multirow{5}{*}{2} & CD & 1168.8 & 621.0 & 360.0 & 26.14 & 146.2 & 44.24 & 11.63 & 25.1 \\
\hline & CDPM & 952.8 & 605.8 & 196.8 & 10.87 & 229.4 & 11.26 & 10.14 & 23.3 \\
\hline & $\mathrm{CDPM}_{U}$ & 1492.6 & 868.2 & 480.4 & 14.66 & 341.2 & 78.40 & 15.28 & 16.9 \\
\hline & Mean & 1204.7 & 698.1 & 345.7 & 17.20 & 238.9 & 44.60 & 12.40 & 21.8 \\
\hline & CV (\%) & 22.6 & 21.1 & 41.2 & 46.20 & 41.0 & 75.20 & 21.40 & 0.16 \\
\hline \multirow{5}{*}{6} & CD & 886.6 & 440.8 & 239.4 & 22.64 & 180.4 & 22.68 & 13.08 & 24.4 \\
\hline & CDPM & 921.0 & 882.6 & 254.7 & 16.88 & 240.0 & 20.20 & 8.25 & 23.1 \\
\hline & $\mathrm{CDPM}_{U}$ & 1004.2 & 925.4 & 274.0 & 14.82 & 189.6 & 18.48 & 10.56 & 16.5 \\
\hline & Mean & 937.3 & 749.6 & 256.0 & 18.10 & 203.3 & 20.50 & 10.60 & 21.3 \\
\hline & CV (\%) & 6.5 & 35.8 & 6.8 & 22.40 & 15.8 & 10.30 & 22.80 & 0.20 \\
\hline \multirow{5}{*}{10} & CD & 1057.4 & 158.2 & 190.8 & 38.14 & 181.4 & 26.44 & 7.84 & 23.9 \\
\hline & CDPM & 577.8 & 324.6 & 160.6 & 26.14 & 160.8 & 45.32 & 9.84 & 23.4 \\
\hline & $\mathrm{CDPM}_{U}$ & 859.2 & 227.8 & 216.0 & 30.60 & 103.8 & 33.44 & 10.66 & 13.6 \\
\hline & Mean & 831.6 & 236.9 & 189.1 & 31.60 & 148.7 & 35.00 & 11.40 & 20.3 \\
\hline & CV (\%) & 29.0 & 35.3 & 14.7 & 19.20 & 27.0 & 27.20 & 40.40 & 0.28 \\
\hline
\end{tabular}

Key: $C D=$ cattle dung

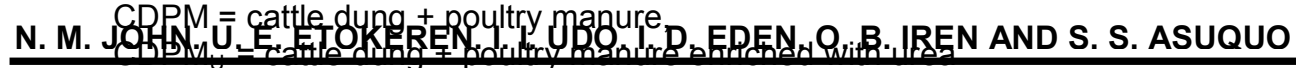




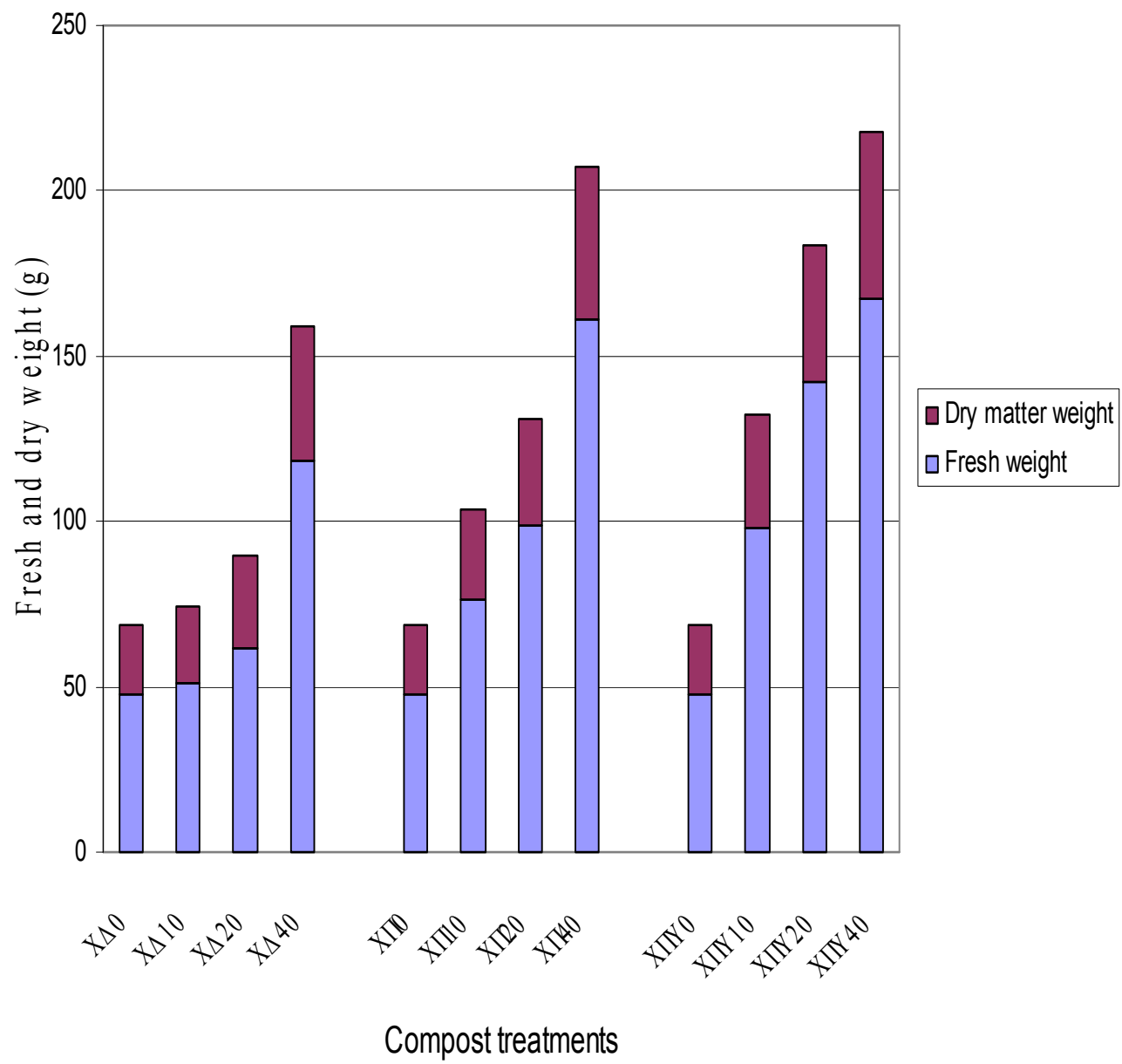

Figure 1: Fresh and dry matter weights of maize plant fertilized with cattle dung/poultry manure compost at 6 weeks after planting.

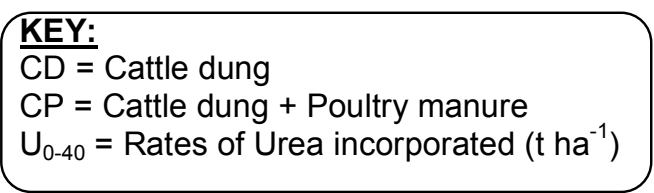

\subsection{CONCLUSION}

The composting of cattle dung with poultry manure provides for the development of suitable soil conditioners with an array of essential plant nutrients for growing crops. Supplementation of this compost with a nitrogen source, such as urea helps to speed up the organic matter decomposition process, and increases the amount of the elements in the compost and availability of the nutrients it contains. Also, the heavy metals concentration in this compost was not toxic to plants. On application, the prepared cattle dung/poultry manure compost supplemented with urea improved the soil fertility status and also resulted in the increased growth and yield of maize.

\section{REFERENCES}

Brady, N. C. and Weil, R. R., 1999. The nature and properties of soil. Prentice- Hall, Inc-Printed in United State of America: 4; 463-466.
Bray, R.H. and Kurtz, L. T., 1945. Determination of total organic and available forms of phosphorus in

55

EFFECTS OF NIT

Canet, R., 2000. Analyzing chemical properties of MSW composts. Biocycle, 72-76.

Cook, G. W., 1981. Agricultural Research. Published by AR Council London. Pp 197-198.

Gomez, K. A. and A. A. Gomez., 1984. Statistical procedures for agricultural research, 2nd edition. John Wiley and Sons, New York, pp. 84 -129 .

Hartly, K. T. and Greenwood, M., 1933. The Effect of small application of farmyard manure on the yield of cereals in Nigeria, Emp. J. Exp. Agric 1: 119-12. 
Hoitink, A. J and Fahy, P.O., 1986. Basis for the control of soil borne plant pathogens with composts. Ann. Rev. Phytopathol., 24: 83 -114.

Jackson, M. L., 1962. The soil chemical analysis; Prentices Hall Inc. Engle Wood N. V., pp. 263268.

John, N. M; Adeoye, G. O. and Sridhar, M. K. C., 1995. Effect of a binding agent and sawdust amendment on the stabilization of compost, soil properties and crop growths, African Soils, 28: 383-394.

Karki, A. B. and Dixit, K., 1989. Biogas field book Sahoyogi Press, Kathmandu, Nepal.

Karki, A. B. and Gairtam, K. M., 1994. Brogas installation from elephant dung at Machan Wildlife Resort, Chitwan, Nepal Biogas Newsletter, Issue No. 45.
Michael, T. and Gilliam, C., 1998. Stabitzation and solidification of hazardous radio active and mixed wastes. www Iritachihta. Com.

SLUS-AK., 1989. Soil and land use survey of Akwa Ibom State Government, Akwa Ibom Printing Press, Uyo, Nigeria.

Sridhar, M. K. C; Ewankhare, E. O; Bammeke, A. O. and Omishakin, M. A., 1985. Composting in a Nigerian Community, Biocycle, USA, 26: 51-54.

Tyler, K. B. and Lorenz, O. A., 1992. Diagnosing nutrient needs of melons through plant tissue analysis. Proc. Am. Soc. Hort. Sci. 85: 393-398

Walkley, A. and Black, T. A., 1934. An Examination of the method for determine soil organic matter and a propose Modification of the chronic acid titration Methods. Soil Science Journal, 37: 2938. 
